\title{
The Scope of Monetary Policy Actions Authorized under the Federal Reserve Act
}

\author{
David H. Small and James A. Clouse*
}

July 19, 2004

* The opinions in this paper are those of the authors and do not necessarily reflect the views of the staff, the Legal Division at the Board of Governors in particular, or members of the Board of Governors of the Federal Reserve System. David Small and James Clouse are economists in the Division of Monetary Affairs at the Board of Governors. Helpful comments were given by Heatherun Allison, Normand Bernard, Cheryl Edwards, Gregg Forte, Oliver Ireland, Donald Kohn, Barbara Lowrey, Brian Madigan, Stephanie Martin, Ann Misback, Wayne Passmore, Thomas Simpson, and Joseph Sommer.

Please address any comments to David Small, Board of Governors of the Federal Reserve System, 20th and C Streets, N.W., Washington, DC 20551, Mail Stop 71, (202) 452-2659, dsmall@frb.gov; or James Clouse, Mail Stop 72, (202) 452-3922, jclouse@frb.gov. 


\begin{abstract}
The Federal Reserve Act authorizes the Federal Reserve to undertake various types of discount window loans and open market operations. While the Federal Reserve generally has not found it necessary to use all types of such authority, there could be circumstances in which the Federal Reserve might need to consider utilizing its statutory authority more broadly than it has in the past.

We examine the limits imposed by the Federal Reserve Act along two dimensions: those types of counterparties and financial instruments with which the Federal Reserve may conduct monetary policy. In doing so, we develop a theme not commonly pursued in the literature - the ways and extent to which the Federal Reserve Act limits the Federal Reserve from taking credit risk onto its balance sheet.

We also provide some historical perspective on how the current powers of the Federal Reserve came to be authorized.
\end{abstract}




\section{Contents}

1 Introduction 1

2 Lending Activities $\quad 7$

2.1 Historical Review . . . . . . . . . . . . . . . . . . 7

2.2 Lending to Depository Institutions . . . . . . . . . . . . . . . . 10

2.3 Lending to Non-Depository Institutions . . . . . . . . . . . . . . . . 14

3 Asset Purchases and Sales 17

3.1 Historical Review . . . . . . . . . . . . . . . . . . . . . 17

3.2 Purchasing Debt of the U.S. Government and of U.S. FSIs . . . . . . 19

3.3 Purchasing State and Local Government Debt . . . . . . . . . . . . 23

3.4 Purchasing Private-Sector Debt . . . . . . . . . . . . 25

3.5 Purchases of Gold, Foreign Exchange, and Foreign Government Obligations . . . . . . . . . . . . . . . . . . . 33

4 Using Options $\quad 35$

5 Conclusion $\quad 36$

6 Appendix: Bills of Exchange $\quad 38$ 


\section{$1 \quad$ Introduction $^{1}$}

To enable the Federal Reserve to change the aggregate supply of the monetary base, and thereby the aggregate quantities of money and credit and the level of interest rates, the Federal Reserve Act ( the "Act") authorizes the Federal Reserve to extend discount window loans and to conduct open market operations. ${ }^{2}$ In order to implement monetary policy effectively, the Federal Reserve generally has not found it necessary to use all of its statutory authority in making discount window loans and conducting open market operations. For example, the Federal Reserve does not currently use its open market authority to purchase bills of exchange or bankers' acceptances. Similarly, in certain circumstances, the Federal Reserve has the legal authority to make loans directly to non-depository institutions that may be secured by a potentially wide variety of collateral, but this authority has not been used for more than 60 years.

There could be circumstances, however, in which the Federal Reserve might need to consider utilizing its statutory authority more broadly. One such circumstance would be if the U.S. government paid off the federal debt completely or to such an extent that lack of depth in the Treasury market had an adverse impact on the functioning of that market. ${ }^{3}$ In such a case, the Federal Reserve would then need to consider conducting open market purchases of assets other than U.S. Treasury debt. A second circumstance would be if the economy were in need of monetary stimulus and the Federal Reserve had already used open market operations to push the

\footnotetext{
${ }^{1}$ This paper is an expanded version of Small and Clouse (2000), which in turn built on early versions of Clouse, Henderson, Orphanides, Small and Tinsley (2003).

${ }^{2}$ The Federal Reserve also can change reserve requirements to affect the aggregate demand for the monetary base. In addition, the Federal Reserve has at times used "selective" instruments such as margin requirements, credit controls, and ceilings on rates paid on deposits at banks and thrifts. The Federal Reserve no longer has statutory authority to impose credit controls or deposit-rate ceilings.

${ }^{3}$ In a period of federal budget surpluses, Fleming (2000) suggested that "If projected [federal] budget surpluses materialize, they could lead to a significant reduction in the Treasury market's size and to a deterioration in the market's liquidity and efficiency.", p. 13.
} 
nominal interest rate on Treasury bills to zero. ${ }^{4}$ In this case, additional open market purchases of Treasury bills may well be ineffective in lowering longer-term Treasury rates further. ${ }^{5}$ In such circumstances, the Federal Reserve could then purchase longermaturity Treasury securities more aggressively than it has done in the past in order to fully exhaust any remaining leeway to lower such interest rates. But, under the law, the Federal Reserve could also purchase assets other than U.S. Treasury securities and could make loans directly to individuals, partnerships, and corporations (IPCs) if certain conditions (discussed below) are met. In both of these cases - nominal interest rates at zero and a significant paydown of Treasury debt - the Federal Reserve might also want to structure its discount window operations with depository institutions in ways different than how it has done so in recent years. ${ }^{6}$

In this paper, we examine the limits imposed by the Act on the Federal Reserve's open market operations and discount window lending. We do not address the operational issues involved in implementing these policy actions. And although we note in passing some of the likely economic effects of such actions, we do not attempt to

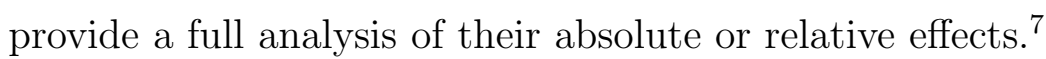

One limit the Federal Reserve faces is whether the counterparty in the monetary policy action must be a depository institution or may be a nondepository institution

\footnotetext{
${ }^{4}$ Monetary policy when the nominal Treasury-bill rate is at zero is discussed in Clouse et al. (2003).

${ }^{5}$ The interest rate on Treasury bills would tend not to fall below zero in an economy in which cash is not taxed and incurs no storage or insurance costs. If the Treasury bill rate were to be negative, holders of Treasury bills would prefer to hold cash because cash is a more liquid asset, and its implicit interest rate of zero would be greater than the negative rate on Treasury bills. Holders of Treasury bills would sell them, driving down their price and increasing their interest rate until the interest rate reaches at least zero. Because of taxes and other technical reasons, nominal yields dropped slightly below zero in the United States in the wake of the Great Depression and in Japan recently (as discussed in footnotes 13 and 21 of Clouse et al. (2003)).

${ }^{6}$ The Federal Reserve has examined what tools it might use to conduct monetary policy should U.S. Treasury debt be paid off. See Beebe and Cumming (2002), Krieger and Madigan (2002) and Hakkio and Lang (2002).

${ }^{7}$ Additional restrictions imposed by the Federal Reserve's own regulations are not a central focus of this paper. Presumably, these restrictions could be changed in a timely manner by the Federal Reserve should the need arise.
} 
or an individual. In making loans, the Federal Reserve faces far fewer statutory restrictions if its counterparty is a depository institution instead of an individual or nondepository institution. But in its conduct of open market operations, it is equally easy (from a legal point of view) for the Federal Reserve to transact with a nondepository institution or individual as it is to transact with a depository institution. Indeed, the Federal Reserve currently conducts open market operations exclusively with about 25 so-called primary government security dealers. All but one of the primary dealers are nondepository institutions, although some are subdivisions of bank holding companies.

The Federal Reserve also faces statutory restrictions on the types of financial instruments that it may buy and sell in open market operations and accept as collateral for discount window loans. Securities issued or guaranteed by the U.S. Treasury or by U.S. agencies can be used both in open market operations and as collateral in discount-window loans extended to depository institutions and to IPCs.

The use of private-sector credit instruments in policy actions is substantially more restricted than is the use of Treasury securities. In making loans to a depository institution, a wide variety of private-sector financial instruments can be used as collateral if the loan takes the form of an advance. ${ }^{8}$ In this case, the depository issues its own promissory note to the Federal Reserve, and the private-sector security is the collateral. ${ }^{9}$ The Federal Reserve also has the statutory authority to make discounts, although this authority has not been used for several decades. In a discount of thirdparty paper for a depository institution, in which case the depository does not issue its own promissory note to the Federal Reserve, the private-sector credit instrument

\footnotetext{
${ }^{8}$ See footnote 21 for a discussion of the differences between advances and discounts.

${ }^{9}$ In 1970, the Board announced new discount window lending procedures that would use "continuing lending agreements" instead of a promissory note for each advance. See Press Release (Dec. 1, 1970). Henceforth, in the context of Federal Reserve advances (under Section 10B of the Federal Reserve Act) we will use the term "promissory note" to include both promissory notes and continuing lending agreements.
} 
that is discounted must have been issued originally to meet "real bills" criteria. ${ }^{10}$ However, in a discount directly for an IPC, a wide variety of private-sector credit instruments can be discounted (without regard to "real bills" restrictions), but such loans are authorized only in "unusual and exigent circumstances" and when the IPC is unable to secure credit from other sources. ${ }^{11}$

Acquiring private-sector credit instruments is considerably more restricted in open market operations than in discounts or advances. The open-market restrictions are on the form of the instrument - it must be a bankers' acceptance or a bill of exchange (with some further "real bills" restrictions ${ }^{12}$ ). There is no express provision in the Federal Reserve Act for the Federal Reserve to use its open-market authority to purchase private-sector promissory notes such as mortgages or corporate bonds or to purchase equities. $^{13}$

An implication of the statutory restrictions of the Federal Reserve Act and the apparent Congressional intent may be that the Federal Reserve faces limitations on the credit risk that it can take onto its balance sheet. In making loans, the Fed-

\footnotetext{
${ }^{10}$ Hackley (1973) describes the "real bills" doctrine, saying:
}

... the Board expounded the principle that all paper offered for discount should be essentially self-liquidating; in other words, that it 'should represent in every case some distinct step in the production or distribution process - the progression of goods from producer to consumer.'

It was not long before this philosophy — the real-bills doctrine - underwent drastic erosion. (p. 191.)

See West (1977) chapter 7 for a discussion of the real bills doctrine as providing the theoretical background for the Federal Reserve Act and chapter 9 for a view of the Federal Reserve's gradual abandonment of the real bills doctrine. Also see Report of the System Committee on Eligible Paper (1962), pp. 68-69, for a characterization of section 13(2) as reflecting the "real bills" doctrine.

When using "real bills" in characterizing aspects of the Federal Reserve Act, we will be using it to include agricultural paper, and therefore applying it to paper issued for "agricultural, industrial, or commercial purpose" as per section 13(2) of the Federal Reserve Act.

${ }^{11}$ When such loans are authorized, the Federal Reserve may have somewhat more leeway in purchasing private-sector securities, as discussed below on page 31 .

${ }^{12}$ As discussed below on page 31 .

${ }^{13}$ The Federal Reserve may also purchase foreign exchange and gold, although the Federal Reserve's holdings of gold are subject to the provisions of the Gold Reserve Act of 1934. 
eral Reserve seems to be implicitly limited from accepting onto its balance sheet any private-sector credit risk other than that of a depository institution - and, in turn, that credit risk is limited because loans to depository institutions must be collateralized. $^{14}$ In asset purchases, the credit risk that the Federal Reserve can take onto its balance sheet seems to be limited by the restrictions on the types of assets it can purchase - discussed below. But even if the Federal Reserve could take significant nondepository credit risk onto its balance sheet, there could be a host of problems if the Federal Reserve began to evaluate credit risk and if its pricing based on those evaluations affected the allocation of credit in the economy.

The Federal Reserve Act provides some flexibility for the Federal Reserve to respond to economic stress through the "incidental powers" provisions of the Act, although this power is limited to being used only when "necessary to carry on the business of banking within the limitations prescribed by this Act" as stated in Section 4(4), paragraph "seventh" of the Federal Reserve Act. ${ }^{15}$ The Federal Reserve used this power to authorize the Federal Reserve Bank of New York to write options in advance of the 1999 year-end in order to promote smooth functioning of money markets in light of potential Y2K pressures, even though the Federal Reserve Act does not explicitly give the Federal Reserve the authority to buy and sell options in particular.

While the focus of this paper is on the Federal Reserve Act and other statutory

\footnotetext{
${ }^{14}$ In discounts and advances, the Federal Reserve accepts some credit risk of the private-sector instruments serving as collateral because if the depository were to default the Federal Reserve would be left holding the private-sector instrument. But this risk would likely be reduced by by the creditworthiness of the depository institution and by the "haircut" the Federal Reserve takes in making discount-window loans (discounts and advances). See footnote 28.

${ }^{15}$ Here and throughout, references to sections of the Federal Reserve Act follow numbering in $\mathrm{Fed}$ eral Reserve Act And Other Statutory Provisions Affecting the Federal Reserve System (As Amended Through October 1998) (1999).

This "incidental powers" provision, discussed more fully in section 4 of this paper, does not authorize the Federal Reserve to exceed or contravene express limitations in the Federal Reserve Act. It does enable the Federal Reserve to exercise powers not expressly authorized by the Act but necessary in order to carry out powers or responsibilities that are express in the Federal Reserve Act.
} 
provisions in their current forms, we provide some historical perspective on how the current powers of the Federal Reserve came to be authorized. In particular, we first focus on the authorization of the Federal Reserve to extend loans under Section 13 of the Federal Reserve Act, and then on the authorization to conduct open market operations under Section 14, following the historical pattern in which each tool was the dominant tool of monetary policy. We finish by discussing the "incidental powers" authority and the use of options. 


\section{Lending Activities}

\subsection{Historical Review}

The Federal Reserve Act, passed in 1913, states that the Federal Reserve System was established

To provide for the establishment of Federal reserve banks, to furnish an elastic currency, to afford means of rediscounting commercial paper, to establish a more effective supervision of banking in the United States, and for other purposes. ${ }^{16}$

In this preamble, the mention of rediscounting commercial paper conveys two key aspects of how the writers of the Act foresaw the Federal Reserve conducting monetary policy. First, the term "rediscounting" presumes that the Federal Reserve would be dealing with member banks but not directly with the public. ${ }^{17}$ Commercial paper would be "discounted" by member banks in the first instance and then "rediscounted" by the Federal Reserve. ${ }^{18}$ Second, the reference to commercial paper indicates that the instruments rediscounted would have been issued for "real bills" purposes - i.e. for "agricultural, industrial, or commercial purposes" and not "covering merely investments or ... for the purpose of carrying or trading in stocks, bonds, or other investment securities, ... "19 These provisions are formalized in section 13(2) of the

\footnotetext{
${ }^{16}$ Preamble to the Federal Reserve Act; Section 1-001 (p. 3) in Federal Reserve Act And Other Statutory Provisions Affecting the Federal Reserve System (As Amended Through October 1998) (1999).

${ }^{17}$ The Federal Reserve was established with the view that it would have little direct interaction with the public, in contrast to practices at that time at the Bank of England and other leading European central banks. See Conway and Patterson (1914), pp. 171-73.

An excellent review of the legislative history of the lending function of the Federal Reserve is provided by Howard Hackley (1973), who served as General Counsel to the Board of Governors of the Federal Reserve System. Also see Report of the System Committee on Eligible Paper (1962) for a review and analysis of discount-window eligibility requirements from the inception of the Federal Reserve to 1962. For a brief overview of current discount window lending practices, see The Federal Reserve System Purposes and Functions (1994) and Clouse (1994).

${ }^{18}$ See McKinley (1960), p. 91. Currently, common practice is to refer to these Federal Reserve operations as "discounts."

${ }^{19}$ See Section 13(2) of the Federal Reserve Act. Commercial paper is defined by Woelfel (1994) as:
} 
Federal Reserve Act, which states

Upon the indorsement of any of its member banks, which shall be deemed a waiver of demand, notice and protest ... any Federal reserve bank may discount notes, drafts, and bills of exchange arising out of actual commercial transactions; that is notes, drafts, and bills of exchange issued or drawn for agricultural, industrial, or commercial purposes, or the proceeds of which have been used, or are to be used, for such purposes ... but such definition shall not include notes, drafts, or bills covering merely investments or issued or drawn for the purpose of carrying or trading in stocks, bonds, or other investment securities, except bonds and notes of the government of the United States.

Reflecting the view that notes, drafts, and bills of exchange include most types of written credit instruments (as discussed below in section 3.4), Reed (1922) summarized section 13(2) of the Federal Reserve Act as giving the Federal Reserve the authority

to discount any of the following: "notes, drafts, and bills of exchange arising out of actual commercial transactions.' Eligible paper was to depend, therefore, upon the nature of the underlying transaction and not upon the form of the paper. ${ }^{20}$

\begin{abstract}
All classes of short-term negotiable instruments (notes, bills, and acceptances) that arise out of commercial, as distinguished from speculative, investment, real estate, personal, or public transactions; short-term notes, bills of exchange, and acceptances arising out of industrial, agricultural, or commercial transactions, the essential qualities of which are short-term maturity (three to six months), automatic or self-liquidating nature, and nonspeculativeness in origin and purpose of use. ...

In the narrower, technical sense, commercial paper consists of notes maturing in less than one year (usually four to six months) which are the direct obligations of issuing mercantile or industrial corporations or copartnerships. (p. 224.)
\end{abstract}

The meaning of "commercial paper" in the Act is closer to the first definition, whereas current usage is more in line with the second and more narrow definition. Willis and Steiner (1926), chapter VII, gives a detailed discussion of the practical problems in implementing these "real bills" restrictions in discount-window operations.

${ }^{20}$ See Reed (1922), p. 110. Also see Willis and Steiner (1926), p. 147. Harris (1933) states the same view (p. 271) and goes on to say

The objective of introducing eligibility provisions in the Federal Reserve Act was to conserve the resources of the reserve banks for commercial purposes and to influence the lending policies of members so that they would hold the maximum possible supplies of acceptable or eligible paper. (p. 296.)

Hardy (1932) also notes that 
This view of the type of lending to be undertaken by the Federal Reserve was broadened considerably during the Great Depression. In lending to member banks, the Federal Reserve was granted authority in 1932 by section 10B of the Act to extend advances. ${ }^{21}$ The collateral for the advances was not restricted by "real bills" considerations, but rather the collateral only had to be "to the satisfaction of [the] Federal Reserve bank." ${ }^{22}$ The Federal Reserve was also granted authority in 1932 to

It was hoped by some critics of our pre-war banking organization that the Federal Reserve System would bring about a change in the standards of commercial bank lending. ... Standards of eligibility would tend to become standards of lending practice. (p. 264)

${ }^{21}$ Regarding the technical distinctions between discounts of third-party paper for member banks and advances to member banks, Hackley (1973) states:

Both discounts and advances are sometimes loosely referred to as discount operations, but the legal distinctions between the two are clear.

In the case of a [section 13(2)] discount, credit is given by a Reserve Bank to a member bank on the basis of eligible paper representing loans made by the member bank to its own customers. ... Any such eligible paper that is offered for discount is transferred to the Reserve Bank with the member bank's endorsement. No note is executed by the member bank. ...

An advance is a simpler operation. The member bank merely executes its own note or, under procedures established in 1971, enters into a continuing lending agreement, and pledges as security paper eligible for discount or purchase by the Reserve Banks. ... If the advance is not repaid at maturity, the Reserve Bank has a direct claim against the member and does not have to resort to the paper pledged as security unless necessary to satisfy that claim. (p. 83.)

As noted by McKinley (1960),

The discount process is more complicated (one of the reasons it is so little used today) because the instruments signed by customers of the member bank have to be accounted for in detail; and must be returned to the member bank, with other collateral substituted, just prior to the various due dates. (p. 94.)

While Hackley and McKiney refer to member banks, under section 19(b)(7) of the Federal Reserve Act (adopted in 1980), "Any depository institution in which transactions accounts or nonpersonal time deposits are held shall be entitled to the same discount and borrowing privileges as member banks."

${ }^{22}$ As stated by McKinley (1960),

By the Great Depression of the 1930's the member banks had so little eligible paper, or were so reluctant to discount what they had, that Carter Glass (now a Senator) had to plead tearfully before the Congress that the 1914 concept of eligible paper had gone awry and expediency dictated new types of collateral. ... For example, Section 10B, first passed in 1932 and made permanent in 1935, provided for advances secured 'to the satisfaction of' the Reserve Banks, which, as cynics pointed out, meant that any 
extend discounts to IPCs - with limitations as discussed below. ${ }^{23}$

\subsection{Lending to Depository Institutions}

As shown in table 1, lending to depository institutions is authorized under several sections of the Federal Reserve Act: Advances are authorized under sections 10B, 13(8), and 13(13), while discounts are authorized under sections 13(2), 13(3), 13(4), $13(6)$ and $13 \mathrm{~A} .{ }^{24}$

The Federal Reserve's broadest authority to extend loans to depositories is under Section 10B. The only restriction on the collateral under that section is that the Reserve Bank making the advance deems the collateral to be satisfactory. ${ }^{25}$

'cat and dog' could now be brought to the central bank and used as collateral. The bitter tears of Senator Glass are understandable in terms of so great a departure from his [real bills] concept of eligible paper. (p. 97.)

${ }^{23}$ Also see Hackley (1973), p. 128.

${ }^{24}$ See footnote 21 for a discussion of the distinction between discounts and advances. Although the Act authorizes discounts secured by the debt of Federal Intermediate Credit Banks, and open market operations using the debt of those banks, these operations are not discussed here because Federal Intermediate Credit Banks no longer exist. In 1987, Congress required the mergers of the Federal Intermediate Credit Banks and the Federal Land Banks, creating the Farm Credit Banks.

The followings provisions in the Federal Reserve Act pertaining to the discount powers of the Federal Reserve are not discussed in this paper: Section 10A (Emergency Advances to Groups of Member Banks), Section 11(b) (Rediscounts of One Reserve Bank for Another), Section 13(5) (Limitation on Discount of Paper of One Borrower), Section 13(10) (Regulation by Board of Governors of Discounts, Purchases, and Sales), Section 13(14) (Receipt of Deposits from, Discount Paper Endorsed by, and Advances to Foreign Banks), and Section 19(7) (Bank Reserves, Discount and Borrowing). See The Federal Reserve Discount Window (1994), pp. iv-vii.

${ }^{25}$ Until recently, a significant amount of discount window lending under $10 \mathrm{~B}$ could have created problems for the Federal Reserve in its attempts to maintain collateral to back Federal Reserve notes because the promissory notes issued by the depository and on which the Federal Reserve made section 10B advances were not among the assets that the Federal Reserve could use to back Federal Reserve notes. This problem would not have occurred with discount window loans under section 13 (and section 13(8) in particular) because the notes, drafts, bills of exchange, and acceptances discounted under section 13 were, and still are, eligible to back Federal Reserve notes, as stated in section 16(2) of the act. (Assets purchased under section 14 of the Act are also generally eligible to back Federal Reserve notes.)

In 1999 (Public Law 106-122, December 6, 1999) the Federal Reserve Act was amended so that the promissory notes on which the Federal Reserve makes advances under section 10B lending are eligible to back Federal Reserve notes. In 2003, Section 16(2) was amended to make any asset of a Federal Reserve Bank eligible to serve as collateral for Federal Reserve notes. 


$\frac{\frac{\text { Borrowers }}{\text { Depositories }}}{\text { 10B Advances* } * *}$

13(8) Advances

13(2) Discounts ***

13(4) Discounts ***

13(6) Discounts ***

13A Discounts *** $\underline{\mathrm{IPCS}} * * * *$

13(13) Advances

13(3) Discounts
Table 1

Credit Instruments

Depository's time and demand notes secured "to the satisfaction of [the] Federal Reserve bank."

Depository's promissory note secured by U.S Treasury, U.S.-guaranteed, U.S. agency, U.S. agency-guaranteed securities, or credit instruments eligible for discount or purchase.

Notes, drafts and bills of exchange meeting "real bills" criteria.

Bills of exchange payable on sight or demand which grow out of the shipment of agricultural goods.

Acceptances that grow out of the shipment of goods (section 13(7)) or for the purpose of furnishing dollar exchange as required by the usages of trade (section 13(12)).

Notes, drafts, and bills of exchange secured by agricultural paper.

IPC's promissory note secured by U.S. Treasury, U.S. agency or U.S. agency-guaranteed obligation.

Notes, drafts, and bills of exchange indorsed or otherwise secured to the satisfaction of the Reserve Bank, in "unusual and exigent circumstances", and provided the IPC cannot secure adequate credit elsewhere or is in a class for which this determination has been made.

*Section 10A provides for advances to groups of member banks, in limited cases.

** Advances are subject to capitalization standards listed in section 10B.

*** Must have been indorsed by a member bank.

**** Depository institutions are corporations and thus qualify for lending authorized for IPCs.

Notes : (1) Maturity restrictions apply to all advances (but not the collateral) except those under section $10 \mathrm{~A}$ and to all securities used as collateral in discounts except those under sections 13(3) and section 13(4). However, under Section 13(4) the Federal Reserve may not hold the discounted instrument for more than ninety days. (2) Section 13(14) authorizes discounts and advances to branches and agencies of foreign banks, subject to restrictions. 
The collateral can be promissory notes, such as corporate bonds and commercial paper, or commercial or industrial loans extended by banks, which are instruments that the Federal Reserve cannot purchase or sell under its open market authority. ${ }^{26}$ (See section 3.3 below.) Reserve Banks currently accept as collateral various types of promissory notes of acceptable quality, including state and local government securities, mortgages covering one- to four-family residences, credit-card receivables, other customer notes, commercial mortgages, and business loans. Apparently, even equity shares would be legally acceptable as collateral for an advance if a Reserve Bank found them to be "satisfactory". In recent decades, the Federal Reserve has extended credit to depositories only through advances (under sections 10B and 13(8)) and has not made any discounts. ${ }^{27}$

Even though the Federal Reserve can extend credit to depositories through advances secured by any of a wide array of instruments, the Federal Reserve takes the credit risk of the collateral onto its balance sheet only to a limited extent. With an advance, the loan to the depository is extended on the basis of a promissory note issued by the depository. During the course of the advance, should the ability of the depository to repay the advance come into question, or should the value of the collateral become insufficient to cover the loan repayments, the Federal Reserve would look to the depository for repayment: The depository therefore retains the credit-risk

\footnotetext{
${ }^{26}$ Under Section 4(8) of the Federal Reserve Act, Federal Reserve Banks shall give consideration to "undue use" of discount-window credit by banks.

${ }^{27}$ Nonetheless, the authorization for discounts by depositories remains important because it potentially affects the scope for open market operations. The bills of exchange (and possibly the bankers' acceptances) eligible to be purchased (under the first paragraph of section 14) are limited to those eligible to be discounted. In "normal" times, the only types of private-sector instruments eligible for discount are restricted to those "real bills" instruments eligible to be discounted by depositories under section 13(2). However, in "unusual and exigent circumstances" the types of private-sector instruments eligible for discount could be widened beyond those meeting "real bills" criteria if discounting to IPCs were authorized by the Federal Reserve Board under section 13(3). In that case, the types of bills of exchange (and possibly bankers' acceptances) eligible for purchase under section 14 could also expand beyond those issued for "real bills" purposes.

The private-sector instruments eligible for purchase in open market operations and the "real bills" restrictions on discounting under section 13(2) are discussed further in section 3.4 of this paper.
} 
of the collateral. ${ }^{28}$ In a discount for a depository institution, although the depository does not issue its own promissory note, the depository must endorse the paper that is discounted. So here too, as in the case of an advance, the credit risk of the underlying collateral stays with the depository institution and the Federal Reserve takes on credit risk of the underlying collateral only if the depository defaults. ${ }^{29}$

If the credit risk of the collateral remains with the depository, lending to depositories would likely do very little to lower credit-risk premiums charged by the depository in making new loans to private-sector borrowers. Such credit risk premiums could be a major factor holding down credit expansion and economic recovery should nominal

\footnotetext{
${ }^{28}$ To further protect itself against credit risk, the Reserve Bank takes a "haircut" on the collateral by giving an advance that is significantly less than the value of the collateral. Then should the depository institution default, the Reserve Bank has a cushion that helps protect it in recouping the full value of the loan.

Additionally, the Federal Deposit Insurance Corporation Improvement Act of 1991 (FDICIA), through its "prompt corrective action" provisions has imposed restrictions on depository institutions in weak capital condition. Among those restrictions

are limitations on access to the Federal Reserve's discount window. Since December 1993, FDICIA has limited the ability of the Federal Reserve to provide credit for undercapitalized and critically undercapitalized institutions. FDICIA stipulates that the Federal Reserve may not lend to an undercapitalized institution for more than 60 days in any 120-day period without incurring a potential limited liability to the FDIC; exceptions to this rule arise if the borrower's primary federal supervisor certifies in writing that the institution is viable or if the Board conducts its own examination of the borrower and the Chairman of the Federal Reserve Board certifies that it is viable.
}

See The Federal Reserve System Purposes and Functions (1994), p. 52. For critically undercapitalized institutions, the Board incurs a potential liability to the FDIC for increases in discount window advances beyond a 5 -day period beginning on the date the institution becomes critically undercapitalized. (See Clouse (1994), p. 975).

${ }^{29}$ Discounts under sections 13(2), 13(4) and 13A require a "waiver of demand, notice and protest", which is discussed by Hackley (1973), p. 22. Hackley also states:

... a borrowing member bank, by virtue of its endorsement of the discounted paper, becomes primarily liable to the Reserve Bank, thus giving the Reserve Bank the right to proceed directly against the member bank rather than against the obligor on the paper discounted. However, if the member bank is insolvent, the Reserve Bank's right of recourse against the member bank is of little value. (p. 245.)

Also see Federal Reserve Bank of Minneapolis v. First Nat. Bank of Eureka, S.D. (1921) at 302.

To further limit its credit-risk exposure, the Federal Reserve presumably would also take a "haircut" on the discount by extending funds that are significantly less than the value of the discounted instrument. See footnote 28. 
rates on Treasury bills be at or near zero and the economy be weak.

\subsection{Lending to Non-Depository Institutions}

The Federal Reserve has the authority to lend directly to individuals, partnerships, and corporations (IPCs) — which could include depository institutions - under sections $13(3)$ and $13(13)$ of the Federal Reserve Act - as shown in table $1 .^{30}$ However, lending under these authorities is subject to very stringent criteria in law and regulation and such lending has not taken place since the Great Depression. ${ }^{31}$ For example, advances under section 13(13), are limited to those

secured by direct obligations of the United States or by any obligation which is a direct obligation of, or fully guaranteed as to principal and interest by, any agency of the United States.

Because IPCs with such collateral could easily sell it in the open market, section 13(13) advances may not have much effect (unless done at subsidized rates) in stimulating aggregate demand.

In contrast, private-sector instruments may lack the liquidity of Treasury debt and, therefore, Federal Reserve loans to non-depository entities that use such instruments as collateral may provide liquidity for those instruments and help stimulate the economy. Such direct loans to non-depository institutions could help remove a potential impediment to economic recovery if depository institutions had become unwilling or very reluctant to provide credit. Hence, we shall focus on section 13(3)

\footnotetext{
${ }^{30}$ In bankruptcy proceedings, disposition of loans to IPCs (with some exceptions including depository institutions) may differ significantly from disposition of loans to depositories. IPC bankruptcies are governed by the Bankruptcy Code and not the Federal Deposit Insurance Act - as is the case for most depositories. The most significant difference between a Code bankruptcy and a banking-law bankruptcy is the automatic stay present in a Code bankruptcy.

${ }^{31}$ Under Section 14(a), the Federal Reserve is granted a broad authority to make loans on gold coin and bullion, which is not discussed further in this paper.
} 
discounts of:

notes, drafts, and bills of exchange when such notes, drafts, and bills of exchange are indorsed or otherwise secured to the satisfaction of the Federal Reserve bank ... ${ }^{32}$

Because notes, drafts, and bills of exchange include most forms of credit instruments, or at least appear to have done so at the time the Act was drafted, section 13(3) provides virtually no restrictions on the form a written credit instrument must take in order to be eligible for discount. ${ }^{33}$ And by requiring merely that the discount be "secured to the satisfaction of the Federal Reserve bank ...", section 13(3) of the Federal Reserve Act imposes no restrictions on the use of funds (such as for "real bills" purposes) for which the discounted instrument was originally issued.

However, in making section 13(3) loans to IPCs, the Federal Reserve must impose some standards that are much more stringent in comparison to those used in lending to a depository. Two particular requirements are that (1) such lending to IPCs is authorized only in "unusual and exigent circumstances", and that (2) the IPC is not able to "secure adequate credit accommodations from other banking institutions." 34 Activation of this authority requires the affirmative vote "of not less than five members" of the Federal Reserve Board. ${ }^{35}$

As stated above in the text from section 13(3), the Federal Reserve Act requires the collateral be "indorsed or otherwise secured to the satisfaction of the Federal

\footnotetext{
${ }^{32}$ The phrase "of the kinds and maturities made eligible for discount for member banks under other provisions of this Act" had appeared immediately after the term "bills of exchange" and before the phrase "when such notes, drafts, and bills of exchange are indorsed ... ". Section 473 of FDICIA amended the Federal Reserve Act to delete this phrase. (See Clouse (1994), p. 975.) This deletion not only broadened the Federal Reserve powers to provide discounts for IPCs, but may have indirectly expanded the class of private-sector securities that the Federal Reserve may purchase - at least in unusual and exigent circumstances. See section 3.4 of this paper.

${ }^{33}$ The distinctions among notes, drafts, and bills of exchange are discussed below in section 3.4

${ }^{34}$ The Federal Reserve's Regulation A (Section 201.3(d): Emergency credit for others) specifies that advances to IPCs would be contemplated only in situations in which failure to advance credit would adversely affect the economy.

${ }^{35}$ Section $11(\mathrm{r})$ of the Act provides exceptions in the event that fewer than five members of the Board are available at the time of the action.
} 
Reserve bank ..." Hackley (1973) has interpreted this provision as indicating:

... it seems clear that it was the intent of Congress that loans should be made only to creditworthy borrowers; in other words, the Reserve Bank should be satisfied that a loan under this authority would be repaid in due course, either by the borrower or by resort to security or the endorsement of a third party. ${ }^{36}$

Under this interpretation, this restriction in section 13(3) could significantly curtail the potential effectiveness of using loans to IPCs to stimulate aggregate demand. In an environment of a sluggish economy and elevated credit risk premiums, lending only to only creditworthy IPCs or accepting only relatively high-quality collateral leaves may limit the scope to lower risk premiums. But, even if the Federal Reserve could take more credit risk onto its balance sheet, any social benefits from the Federal Reserve doing so would need to be balanced against the potentially substantial drawbacks associated with placing the Federal Reserve squarely in the process of allocating credit among private sector borrowers.

\footnotetext{
${ }^{36}$ Hackley (1973), p. 129.
} 


\section{$3 \quad$ Asset Purchases and Sales}

\subsection{Historical Review}

Asset purchases and sales for the purpose of open market operations were authorized in section 14 of the original Federal Reserve Act, but played only an auxiliary role in the conduct of monetary policy from the inception of the Federal Reserve until the early 1920s. ${ }^{37}$ During this period, Reserve Banks purchased financial assets to obtain income with which to pay expenses and purchased bankers' acceptances with the additional objective of helping to develop a U.S. market for bankers' acceptances. ${ }^{38}$ Open market operations also were seen as a tool with which the Federal Reserve could take the initiative in injecting reserves (rather than waiting for member banks to apply for discounts) and in smoothing out market dislocations. ${ }^{39}$ Assets purchased by Federal Reserve Banks included state and local government debt, bankers' acceptances, and U.S. government securities.

\footnotetext{
${ }^{37}$ See Youngdahl (1960), West (1977) (chapters 9 and 10) for discussions of the early history of open market operations.

In 1913, section 14 also impacted the Federal Reserve through Section 19, which provided that "[a]ny Federal reserve bank may receive from member banks as reserves, not exceeding one-half of each installment, eligible paper as described in Section 14 properly indorsed and acceptable to the said bank." The provision was repealed in 1917.

${ }^{38}$ See Tenth Annual Report of the Federal Reserve Board: Covering Operations for the Year 1923 (1924) p. 12, Youngdahl (1960) pp. 116-117, and West (1977) p. 223. See Willis and Steiner (1926) (Chapter XVI) for an extended discussion of the use of open market purchases to develop the market for bankers' acceptances. (H. Parker Willis served as the Secretary of the Federal Reserve Board and William H. Steiner served as the Acting Chief of the Division of Analysis and Research of the Federal Reserve Board.)

${ }^{39}$ In Circular No. 8, the Federal Reserve Board offered its view of the role of open market operations, saying:
}

The open market provisions of the act are of large importance in two ways:

(a) In permitting Federal reserve banks to place their resources at the disposal of constituent or member banks even when such constituent or member banks do not apply for rediscounts, ....

(b) In permitting a reserve bank in one district which has surplus funds to relieve the strain upon reserve banks in other districts...

See First Annual Report of the Federal Reserve Board (1915), p. 156. 
In the early 1920s, the Federal Reserve began to see open market operations as an effective tool with which it could, and should, help determine and control the aggregate quantity of credit. ${ }^{40}$ In particular, the Board created the Open Market Investment Committee for the Federal Reserve System in 1923 and adopted the following principle for open market operations:

That the time, manner, character, and volume of open market investments purchased by Federal reserve banks be governed with primary regard to the accommodation of commerce and business and the effect of such purchases or sales on the general credit situation." 41

In 1933, Congress amended the Act to provide for the FOMC by statute. ${ }^{42}$ The FOMC was given central control over open market operations sugject to the principle

that

... open market operations shall be governed with a view to accommodating commerce and business and with regard to their bearing upon the general credit situation of the country. ${ }^{43}$

\begin{abstract}
${ }^{40}$ See Willis (1936) (chapter X) for a discussion of the practical considerations and theoretical reasons behind the shift in the Federal Reserves' emphasis from discount window lending to open market operations. Also see West (1977) (chapter 9) and Meltzer (2003) (chapter 4) for discussions of the Federal Reserve's shifting its main tool of monetary policy from being the discount window (subject to the real bills doctrine) to being open market operations.
\end{abstract}

${ }^{41}$ See Tenth Annual Report of the Federal Reserve Board: Covering Operations for the Year 1923 (1924), p. 16. This annual report also contains a discourse (starting on page 11) on the Federal Reserve Board's views on open market operations, given that the year of 1923 "witnessed a considerable development in the scope, purpose, and method of these open market operations."

On pages 33 and 34, the Board distinguished between the "qualitative" credit restrictions envisioned in the Federal Reserve Act-relating to the real bills concepts of paper eligible for purchase and discount and to the principle of "accommodating commerce and business" as stated Federal Reserve Act- and the "quantitative" restrictions on the aggregate amount credit that also are necessary for the successful conduct of monetary policy. Also see Strong (1930) for a discussion of the limitations of the real bills doctrine, the use of qualitative restrictions, and the advantages of using open market operations to impose quantitative restrictions on the growth of credit.

Also see Congressional testimony in Operation of the National and Federal Reserve Banking Systems (1931), pp. 802-808, which contains a statement by the Federal Reserve Bank of New York and a memorandum by Gov. Benjamin Strong of the Federal Reserve Bank of New York justifying the new and expanded use of open market operations.

${ }^{42}$ Act of June 16, 1933, 48 stat. 162, 168

${ }^{43}$ See sections $12 \mathrm{~A}(\mathrm{~b})$ and $12 \mathrm{~A}(\mathrm{c})$ of the Federal Reserve Act in Federal Reserve Act And Other Statutory Provisions Affecting the Federal Reserve System (As Amended Through October 1998) (1999), p. 29. 
Since that time, the Federal Reserve has gradually narrowed the scope of securities that it purchases (or with which it conducts repurchase agreements in the open market). The last purchases of state or local government debt were undertaken in 1933. ${ }^{44}$ The Federal Reserve ceased conducting open market operations in bankers' acceptances in 1977 and discontinued the use of repurchase agreements on bankers' acceptances to manage reserves in $1984 .{ }^{45}$ Outright purchases of U.S. agency debt started in 1971 and ceased in 1981, although repurchase agreements in such debt continue to be used by the Federal Reserve to conduct monetary policy. Currently, the Federal Reserve also enters repurchase agreements on mortgage-backed securities issued by U.S. federal agencies, conducts open market purchases and sales in Treasury debt, and enters into repurchase agreements on U.S. Treasury debt.

\subsection{Purchasing Debt of the U.S. Government and of U.S. FSIs}

As shown in table 2, the Federal Reserve's authority to purchase debt issued or guaranteed by the U.S. government is provided in section 14(b)(1) of the Federal Reserve Act, which states:

\footnotetext{
${ }^{44}$ See Recission of Regulation E (1978).

${ }^{45}$ See Federal Reserve press releases on March 18, 1977 and on April 9, 1984. The Federal Reserve dropped the use of outright purchases of, and repurchase agreements in, bankers' acceptances, in part, because (1) such operations in Treasury securities would suffice in conducting monetary policy, (2) the market for bankers' acceptances was well developed and no longer needed the support provided by Federal Reserve activity in bankers' acceptances, (3) the Federal Reserve was concerned that its willingness or reluctance to buy bankers' acceptances from a particular bank could be read by market participants as a "seal of good housekeeping" from the Federal Reserve, (4) participation in this market by the Federal Reserve was not giving it insights into market conditions that could not be achieved in other ways, (5) the banking system had recovered from earlier troubles and, therefore, withdrawal of the Federal Reserve from the banker's acceptance market likely would not be seen as a sign of lack of confidence by the Federal Reserve in the banking sector as a whole, and (6) operations in bankers' acceptances exposed the Federal Reserve to some, although limited, credit risk. See Transcript of the Federal Open Market Committee Meeting of March 16, 1984 (1984), pp. 17-20; and Recommendations Regarding Operations in Bankers' Acceptances (1977).
} 
Table 2

Types of Financial Assets That May be Purchased by the Federal Reserve

$\frac{\text { Obligations: }^{*}}{\text { U.S. Government Obligations }}$
14(b)(1)
14(b)(2)
Private Sector Debt**
14 (first paragraph) $)^{* *}$
$14(\mathrm{c})$
$13(4) * * * *$

State and Local Government Debt $14(\mathrm{~b})(1)$

Foreign Government Debt $14(\mathrm{~b})(1) * * * * *$ $\underline{\text { Assets }}$

All U.S. Treasury securities and securities which are fully guaranteed by the United States

U.S. agency securities and those securities fully guaranteed by U.S. agencies.

“...cable transfers and bankers' acceptances and bills of exchange of the kinds and maturities ... eligible for rediscount."

"bills of exchange arising out of commercial transactions ..."

Bills of exchange payable on sight or demand which grow out of the shipment of agricultural goods.

bills, notes, revenue bonds and warrants used in anticipation of taxes or assured revenues

Direct obligations and securities that are fully guaranteed by a foreign government or agency thereof.

* Gold may be purchased under section 14(a) subject to the Gold Reserve Act of 1934.

$* *$ Subject to maturity restrictions.

*** As discussed in section 3.4 below, the phrase "of the kinds and maturities ... eligible for rediscount" in the first paragraph of section 14 may apply to both bankers' acceptances and bills of exchange or just to the latter.

**** The purchased asset may not be held by the Federal Reserve for more than ninety days and must have been indorsed by a member bank.

***** The legislative history of the Federal Reserve Act indicates that the Federal Reserve would use this authority to invest foreign currency holdings in foreign government obligations and not to "bail out" foreign governments. 
... any bonds, notes, or other obligations which are direct obligations of the United States or which are fully guaranteed by the United States as to the principal and interest may be bought and sold without regard to maturities but only in the open market. ${ }^{46}$

Included in the obligations authorized for purchase by section 14(b)(1) is any debt the U.S. government guarantees, including that of any agency that is part of the U.S. government. Under section 14(b)(2), the Federal Reserve also may purchase

any obligation which is a direct obligation of, or fully guaranteed as to principal and interest by, any agency of the United States.

This section provides the authority for the Federal Reserve to purchase debt obligations that are not obligations of the United States and not guaranteed by the United States but are issued or guaranteed by agencies of the United States.

A list of obligations seen as eligible for purchase by the Federal Reserve under sections 14(b)(1) or 14(b)(2) was published by the Federal Reserve Board in 1968 and updated in 1969, 1971, and 1972. ${ }^{47}$ This list includes obligations issued or guaranteed by certain U.S. financial services institutions (U.S. FSIs). ${ }^{48}$

\footnotetext{
${ }^{46}$ The Federal Open Market Committee has concluded that the restriction that such purchases must be in the open market "does not prohibit the exchange of maturing Government securities for an equal amount of new securities carrying the conversion privilege ..." See Twenty-Fourth Annual Report of the Federal Reserve Board: Covering Operations for the Year 1937 (1938), p. 211.

${ }^{47}$ See Federal Reserve Bulletins: 1968 p. 1012; 1969 p. 150 and p. 355; 1971 p. 399; and 1972 p. 983. Also see "Board Interpretation of Regulation A" in Monetary Policy and Reserve Requirements Handbook (1998), section 2-040. As noted in this interpretation, this list of obligations of agencies of the United States was constructed to denote obligations eligible as collateral in advances to depository institutions under section 13(8) of the Federal Reserve Act and not to denote obligations eligible in open market operations. However, as noted in this interpretation, the Federal Reserve is authorized under section 13(8) of the Federal Reserve Act to make advances "secured by such obligations as are eligible for purchase under section 14(b) of ... [the Federal Reserve] Act." (Underlining added.) Therefore, in determining which securities were eligible as collateral for advances under section 13(8) the Board was making the necessary prior determination that those securities were eligible for purchase in open market operations.
}

${ }^{48}$ We use the term "U.S. financial service institutions" to refer to both government corporations and government-sponsored agencies that provide financial services, following terminology used by the Government Accounting Office in Financial Services Institutions: Information for Assessing the Government's Potential Financial Exposure (1998) (pp. 2 - 3 and Appendix II). Government corporations "have assets wholly owned by the federal government or have both government and 
In particular, U.S. FSIs issue two types of securities: direct debt obligations and "guaranteed certificates of participation" such as mortgage pass-through certificates, which are guaranteed by the U.S. FSI as to the timely payment of principal and interest. ${ }^{49}$ A key economic issue regarding open market purchases of these securities is the extent to which they carry risk or liquidity premiums over Treasury securities, and if these premiums can be lowered by Federal Reserve purchases of these securities. Interest rates on U.S. FSI pass-through certificates incorporate risk premiums, but these premiums do not directly reflect the credit risk on the underlying securities in the pools on which the pass-throughs are written. The U.S. FSI issuing the certificates accepts the credit risk as part of its guarantee of the timely payment of interest and principal to the holders of the pass-through certificates. ${ }^{50}$

However, two types of risks could remain in the pass-through certificates. First, there is the risk of prepayments on the underlying securities: Prepayments are passed onto the holders of the pass-throughs and need to be reinvested-predictably at lower interest rates. Second, pass-through certificates could carry the risk that the U.S. FSI issuing the certificate will not be able to honor its guarantee of the timely payment of interest and principal. However, there is no such risk for government corporations to the extent that they are backed by the full faith and credit of the U.S. government. And currently, financial markets may perceive little such risk for governmentsponsored enterprises, which markets apparently assume are backed implicitly by the

private equity," while government-sponsored enterprises are "federally established, privately owned" entities (p. 3). The former includes the Federal Housing Administration and the Government National Mortgage Association (Ginnie Mae), for example, and the latter includes Federal Home Loan Banks, the Federal Home Loan Mortgage Corporation (Freddie Mac), and the Federal National Mortgage Corporation (Fannie Mae), for example.

${ }^{49} \mathrm{~A}$ mortgage pass-through certificate is a security representing an interest in an underlying pool of mortgages. Payments received on the underlying pool are passed through to the security investor. See the definition of pass-through certificate in Woelfel (1994), p. 891.

${ }^{50}$ See Lowell (1995), pp. 30 - 34. 
U.S. government and which are regulated by a variety of government agencies. ${ }^{51}$

U.S. FSIs also issue direct debt, and the Federal Reserve may have the authority under sections 14(b)(1) and 14(b)(2) to purchase this debt in the open market and thereby possibly lower the institution's funding costs. As just noted, these institutions benefit from the actual or perceived backing by the U.S. government, which keeps this default risk relatively low.

Nonetheless, some risk of holding debt of U.S. FSIs is incorporated into market interest rates. We have data on the rates on Fannie Mae benchmark notes and on Freddie Mac reference notes only for a few years. The behavior of the spreads of these rates over the ten-year Treasury yield during the period of highly elevated risk aversion in the fall of 1998 due to international financial fragility gives some indication that these spreads rise in periods of increased uncertainty and demands for liquidity. The spreads of rates on Fannie Mae benchmark notes and rates on Freddie Mac reference notes over the ten-year Treasury yield rose from about 40 basis points before mid-August 1998 to as much as 70 to 80 basis points in October 1998.

If, as discussed in Clouse et al. (2003), asset prices are influenced by changes in the relative supplies of assets, then Federal Reserve purchases of U.S. FSI direct and guaranteed debt could potentially lower the risk premiums on this debt. Such purchases may be helpful in stimulating aggregate demand even when Treasury rates are at zero.

\subsection{Purchasing State and Local Government Debt}

The authority under which the Federal Reserve may purchase debt instruments of state and local governments is contained in section 14(b)(1) of the Federal Reserve Act, giving the Federal Reserve the authority

To buy and sell, at home and abroad, ... bills, notes, revenue bonds, and warrants with a maturity from date of purchase of not exceeding six

\footnotetext{
${ }^{51}$ For analyses of risk associated with government-sponsored enterprises, see Lowell (1995), Jaffee (2003), Six Voluntary Initiatives (2004), and Office of Federal Housing Enterprise Oversight (2004).
} 
months, issued in anticipation of the collection of taxes or in anticipation of the receipt of assured revenues by any State, county, district, political subdivision, or municipality in the continental United States, including irrigation, drainage, and reclamation projects. ${ }^{52}$

\footnotetext{
${ }^{52}$ Section 1 of the the Federal Reserve Act defines "the continental United States" to mean "the States of the United States and the District of Columbia," thus including Alaska and Hawaii. Garcia, ed (1973) defines a warrant as
}

A short-term obligation of a municipality, or other political subdivision, constituting part of its floating debt. A warrant is a revenue obligation issued in anticipation of tax collection.

Garcia, ed (1973) describes a municipal warrant, saying

A municipal warrant may originate as an order given by a municipal official acting under proper authority upon the treasurer of such municipality to pay a certain person, firm, or corporation a certain sum of money or goods or services advanced, and which when presented to the treasurer, cannot be paid for lack of funds. When stamped as follows: 'Presented but not paid on account of lack of funds. This warrant bears interest from this date until paid at the rate of per cent,' together with the treasurer's signature, the order becomes a warrant.

Daniel (1903) defines a municipal warrant in saying:

Frequently a draft, order, or warrant is drawn by one officer of a municipal corporation upon another; or by the selectman of a town, or supervisors of a county, upon an officer, for the payment of corporate indebtedness to the payee. The intention in such a case is, as a general rule, to furnish vouchers to the proper disbursing officer, and not to put negotiable instruments in circulation. And it has been generally, and as we think justly, considered that such drafts, orders, or warrants are not negotiable instruments, and cannot be regarded as either bills of exchange or promissory notes, cutting out equities as against the corporation--on the ground that there is no implied authority in such officers to execute negotiable instruments. (p. 451, vol. 1.)

Woelfel (1994) provides a modern definition of a revenue bond, saying

Bonds issued by municipalities with principal and interest payable from revenues or income from municipally owned or state-owned plants, toll roads or bridges, or public works, such as water works, electric light and power plant, port authority, railroad, etc. Thus revenue bonds are secured by the property and income of a city-owned or stateowned enterprise. The full faith and credit of the state or municipality, however, are not pledged behind revenue bonds, so such issues are classified as "limited liability" debt of the issuing governmental units.

Note: The term "revenue bond" may have had a meaning at the time of the writing of the Federal Reserve Act that is different from its current meaning as given above. For example, in editions subsequent to the 1924 edition of Munn (1924), revenue bonds generally were defined as above, but the 1924 edition defines revenue bonds as

Bonds issued temporarily by a municipality or other civil division in order to provided funds for current expenditure until taxes or other income due, can be collected. Revenue bonds are usually in the form of short-term notes and payable on the next tax date. They are also known as tax relief or tax arrearage bonds. 
Three particular aspects of this authorization are noteworthy. First, this authorization does not limit Federal Reserve purchases of state and local government debt to the open market. Reserve Banks may purchase such obligations directly from State or local governments. ${ }^{53}$ Second, the Act requires only that debt purchased have a maturity of six months or less at the time of purchase by the Federal Reserve, implying that eligible debt may have had a longer original maturity.

Third, the state or local government debt must have been issued "in anticipation of the collection of taxes or in anticipation of the receipt of assured revenues ..." The extent to which this phrase restricts the state and local government debt that may be purchased by the Federal Reserve is unclear. For example, this phrase could render revenue bonds (current definition) ineligible for purchase because the amount of revenue generated by the project financed by the revenue bond might be somewhat uncertain and not be "assured" within the meaning of the Act.

\subsection{Purchasing Private-Sector Debt}

As shown in table 2, the statutory provisions governing open market purchases of private-sector debt are contained in sections 14 and 13(4) of the Federal Reserve Act. The most general provision for the purchase of private-sector debt is contained in the first paragraph of section 14, which authorizes the Federal Reserve to

... purchase and sell in the open market ... cable transfers and bankers' acceptances and bills of exchange of the kinds and maturities by this Act made eligible for rediscount, with or without the indorsement of a member bank. ${ }^{54}$

Similar to these current and earlier definitions of revenue bonds are the ones used in the 1938 and the 1931 editions of Financial Statistics of the United States (various years), respectively.

${ }^{53}$ See Recission of Regulation E (1978).

${ }^{54}$ See the first paragraph of section 14 of the Federal Reserve Act in Federal Reserve Act And Other Statutory Provisions Affecting the Federal Reserve System (As Amended Through October 1998) (1999), p. 35. That part of the Federal Reserve Act also authorizes these purchases only "from or to domestic or foreign banks, firms, corporations, or individuals." 
This provisions sets forth three limitations on purchases of private-market debt: (1) only cable transfers, bankers' acceptances, and bills of exchange are eligible for purchase or sale; (2) the bills of exchange (and possibly the bankers' acceptances) must be eligible for rediscount; and (3) the purchases and sales must be done in the open market.

The first limitation restricts the instruments to be one of the three mentioned types. The first type of instrument, cable transfers, simply means foreign exchange. ${ }^{55}$ To define and distinguish bankers' acceptances and bills of exchange, we first note that, as stated by Woelfel (1994),

From a legal standpoint, credit instruments may be divided into two classes - promises to pay and orders to pay. ${ }^{56}$

A promise to pay is a two-party instrument in which party A promises to pay party $\mathrm{B}$ - an example of which is a bond. In contrast, an order to pay is a three-party instrument: an order by party A that party B make a payment to party $\mathrm{C}$ - an example of which is a personal check (in which case party B is the bank on which the check is drawn. $)^{57}$ For a discussion of how the economic functions and the legal rights and obligations associated with a bill of exchange differ from those associated

\footnotetext{
${ }^{55}$ At the time the Federal Reserve Act was passed in 1913, cable transfers were the method by which foreign exchange could be purchased or sold: The purchase of foreign exchange was referred to as the purchase of a cable transfer. For example, see Rufener (1934) pp. 316 and 346.

${ }^{56}$ See definition of "credit instruments", p. 269. Also see Chandler (1948) p. 154, Fundamentals of Banking: How a Bank Works (1943) pp. 84-85, and Scott (1916) pp. 95-97.

${ }^{57}$ See Chandler (1948) pp. 154-156, Fundamentals of Banking: How a Bank Works (1943) pp. 85 and 351, Bigelow (1928) p. 37, Scott (1916) pp. 95 and 96, Daniel (1903) pp. 37-39, vol. 1, and The American and English Encyclopedia of Law (1897), pp. 76 and 77. Chandler (p. 156) notes that in some cases only two persons are involved in an order to pay because party A and party $\mathrm{C}$ (the drawer and the payee, respectively) are the same person. Also see Parsons (1863), pp. 62-65, vol.1.: "For it is very common for a man to draw upon himself; and it has long been held that such an instrument is a good bill of exchange. But it may be treated as a promissory note, at the election of the holder... And it may be laid down as a general rule, that whenever it is doubtful, upon the face of an instrument, whether it was intended as a bill of exchange or a promissory note, and it possesses the requisites of each, it may be treated as either, at the option of the holder." Also see Title II, Article 1, Section 130 of The Negotiable Instruments Law, on p. 546 of the Appendix of Bigelow (1928). And see Daniel (1903), pp. 150-151, (Chapter 5, Section 1).
} 
with a promise to pay, see the Appendix. Providing specific examples of orders to pay and promises to pay, Woelfel (1994) states:

The chief types of promises to pay are promissory notes, trade acceptances, bank acceptances, bonds, coupons, and certificates of debt.

The chief types of orders to pay are checks, drafts, bills of exchange, money orders, telegraphic transfers, cable transfers, and letters of credit. ${ }^{58}$

Although there are slight differences among how "orders to pay", "drafts" and "bills of exchange" are used, these terms are virtually synonymous. ${ }^{59}$

${ }^{58}$ Page 269. Underlining added. Section 13(2) of the Federal Reserve Act gives the Federal Reserve the authority to define the character of paper eligible for discount. In 1917, it provided the following definitions:

A promissory note ... is defined as an unconditional promise, in writing, signed by the maker, to pay, in the United States, at a fixed or determinable future time, a sum certain in dollars to order or to bearer. (underlining added)

A bill of exchange, ... is defined as an unconditional order, in writing, addressed by one person to another, other than to a banker as defined under IV(a), signed by the person giving it, requiring the person to whom it is addressed to pay in the United States, at a fixed or determinable future time, a sum certain in dollars to the order of a specified person ... (underlining added)

See Third Annual Report of the Federal Reserve Board (1917), Regulation A, Series of 1916, p. 154 for the definition of promissory note (for the purpose of rediscounts) and Regulation B, Series of 1916, p. 157 for the definition of bill of exchange (for the purpose of open market operations).

Daniel (1903) defines a letter of credit (used above as an example of an order to pay) as " a letter of request, whereby one person requests some other person to advance money or give credit to a third person, and promises that that he will repay or guarantee the same to the person making the advancement, or accept bills drawn on himself, for the like amount." (p. 820, vol. 2) and "Letters of credit very much resemble bills of exchange in some particulars, but they are not bills." (p. 832, vol.2)

${ }^{59}$ In defining a bill of exchange, Woelfel (1994) (p. 135) states:

The Uniform Commercial Code (Sec. 3-104) provides that a writing which complies with the requirements of that section for any writing to be a negotiable instrument is a DRAFT (bill of exchange) if it is an order.

The terms bill of exchange and draft are used interchangeably, but the former is usually applied to an order to pay arising out of a foreign transaction, while the latter term is more often reserved for domestic transactions. Technically, moreover, a bill of exchange is always a negotiable instrument, whereas a draft may be nonnegotiable.

A bill of exchange is a three-party instrument in which the first party (drawer) draws an order for the payment of a sum certain on a second party (the drawee) for payment to a third party (payee) at a definite future time. According to the Uniform Commercial Code, a bill of exchange is the same as a draft. (underlining added)

Also, Fundamentals of Banking: How a Bank Works (1943) uses "bills of exchange" and "drafts" interchangeably in the definitions of these terms (pp. 532 and 539.) 
So although the use of the term "bills of exchange" authorizes the purchase of virtually the entire class of orders to pay, only one particular type of promise to pay is authorized for purchase under the first paragraph of section 14-and that is a banker's acceptance. As stated by Fundamentals of Banking: How a Bank Works (1943), a banker's acceptance is a promise to pay (note) because of the act of acceptance: A banker's acceptance is defined as

... a time draft (bill of exchange) on the face of which the drawee has written the word 'accepted,' .... Thus the instrument becomes a promise to pay. ${ }^{60}$

In this definition, the drawee and the acceptor are the same party, but apparently this need not be the case. ${ }^{61}$

The Federal Reserve Act places a restriction on the Federal Reserve's open market operations because promises to pay other than bankers' acceptances are not made eligible for purchase under the first paragraph of section 14 or under any other part of

\footnotetext{
${ }^{60}$ See Fundamentals of Banking: How a Bank Works (1943), p. 353. Many authors note the similarities between bankers' acceptances and promissory notes, but do not explicitly say that bankers' acceptances are notes. For example, Bigelow (1928) (p. 116) states: "If the acceptance [of a bill of exchange] be general the holder now has an unconditional recourse against at least one party to the instrument, who is bound absolutely to pay; whereas before acceptance his recourse was against conditional parties only, drawer and indorsers. By a general acceptance, therefore, the drawee becomes, like the maker of a note, an absolute promisor, and the primary party, ..." (Underlining added.) Likewise Daniel (1903) states "The effect of the acceptance of a bill is to constitute the acceptor the principal debtor. The bill becomes by the acceptance very similar to a promissory note - the acceptor being the promisor, and the drawer standing in relation of an indorser." (p. 527, vol. 1)

If a banker's acceptance is not defined as a type of note, then no notes are eligible for purchase under the first paragraph of section 14 of the Federal Reserve Act.

Section 3-409(a) of the Uniform Commercial Code indicates that 'accepted' need not be written on the instrument but that the mere signature of the drawee is sufficient.

${ }^{61}$ Section 13(2) of the Federal Reserve Act gives the Federal Reserve the authority to define the character of paper eligible for discount. In its definition in 1917, the Federal Reserve did not require the drawee and the acceptor to be the same party:
}

A bankers' acceptance .... is a bill of exchange of which the acceptor is a bank or trust company, or a firm, person, company, or corporation engaged in the business of granting bankers' acceptance credits.

See Third Annual Report of the Federal Reserve Board (1917), Regulation B, Series of 1916, p. 157. 
the Federal Reserve Act. ${ }^{62}$ Thus there is no express authority for the Federal Reserve to purchase under its open market authority such promises to pay as corporate bonds, bank loans, mortgages and credit-card receivables, for example. ${ }^{63}$ Nor is there any express authorization for the Federal Reserve to purchase equities.

The second limitation imposed on open market operations by the first paragraph of section 14 of the Federal Reserve Act is that to be eligible for purchase, the credit instruments must be "of the kinds and maturities ... eligible for discount." This phrase clearly does not modify cable transfers. ${ }^{64}$ However, it is not clear from the text whether this phrase modifies both bankers' acceptances and bills of exchange or only the latter - although the Federal Reserve's interpretation appears to have

\footnotetext{
${ }^{62}$ Except for securities issued by or guaranteed by the U.S. Treasury or U.S. agencies, all of which are promises to pay but are eligible for purchase under sections 14(b)(1) and 14(b)(2).

${ }^{63}$ Youngman (1921) argued that it was a mistake to restrict the Federal Reserve from purchasing private-sector notes (i.e. promises to pay) in its open market operations, asking

Why should our central banks confine their open market purchases to a type of paper [bill of exchange] that represents a relatively small proportion of general banking business? ... Why should not the provisions of the Federal Reserve act be changed so as to empower the federal reserve banks to extend their open market operations to cover notes as well as bills growing out of commercial transactions, since this is a country whose banking needs are after all primarily domestic and whose banking accommodation for domestic purposes is based principally on the note? (See pp. 479-480.)
}

Willis and Steiner (1926) note:

It should be observed that the Act as finally passed excludes the promissory note, the former leading American credit instrument, from open market purchase by reserve banks. In large part this was due to the feeling that the note, not related to a specific transaction nor necessarily bearing an endorsement, could be identified only with difficulty and hence involved too many hazards.

For a proposed amendment to section 14 of the Federal Reserve Act that would have included notes as eligible for purchase see Congressional Record (1913), December 19, p. 1192. As indicated, the amendment was rejected.

${ }^{64}$ In the first paragraph of section 14, the insertion of the word "and" and the lack of a comma after "cable transfers" demonstrate that the authority to purchase and sell cable transfers is not conditioned on a requirement that they be eligible for rediscount. Furthermore, cable transfers have never been eligible for rediscount. 
been that it modifies only the latter. ${ }^{65}$ Hereafter, in this paper, we will assume this interpretation is correct.

In normal circumstances, the restriction that the bills of exchange must be eligible for discount would significantly limit the types of bills of exchange that could be purchased. In these circumstances, discounting would be limited to the specific types of bills of exchange eligible for discount under sections 13(4), 13(6) or 13A of the Federal Reserve Act (see table 1) or would be subject to the "real bills" restrictions of section 13(2), which authorizes the discounting of:

... bills of exchange arising out of actual commercial transactions; that is, ... bills of exchange issued or drawn for agricultural, industrial, or commercial purposes ... but such definition shall not include ... bills covering merely investments or issued or drawn for the purpose of carrying or trading in stocks, bonds, or other investment securities, except bonds and notes of the government of the United States. ${ }^{66}$

\footnotetext{
${ }^{65}$ In 1923, the Federal Reserve Bulletin published sections of a letter from the Board's general counsel that stated:

At first glance, it would appear that only bankers' acceptances of the kinds and maturities made eligible for rediscount could be purchased in the open market, but, upon careful consideration of the language of this section, it will be found that the phrase 'of the kinds and maturities by this act made eligible for rediscount' qualifies only 'bills of exchange' and does not qualify 'bankers' acceptances'. ... It will be seen, therefore, that Federal reserve banks in their open market transactions are not limited to the purchase of acceptances which, under section $13, \ldots$ Federal reserve banks are authorized to discount. According to the Board's interpretation of section 14, the only limit upon the open market purchase power of bankers' acceptances by Federal reserve banks is to be found in the rules and regulations of the board, and these are embodied in Regulation B. (See Acceptance, discount, and open-market purchases of bankers' acceptances (1923), p. 317.)
}

Reed (1922) cites a letter to him that also indicates the Federal Reserve held the view that the phrase 'of the kinds and maturities by this act made eligible for rediscount' does not qualify bankers' acceptances. This letter states that the Federal Reserve Board

... has authorized the purchase in the open market by Federal reserve banks of acceptances growing out of the domestic storage of goods, although the only acceptances eligible for rediscount as growing out of domestic storage transactions are those growing out of the storage of readily marketable staples. The term "goods" is, of course, more inclusive than the term "readily marketable staples." (Underlining added. See Reed (1922), p. 192.)

${ }^{66}$ Immediately preceeding this text is the wording "Upon indorsement of any of its member 
But, if the Board of Governors of the Federal Reserve System found that there were "unusual and exigent circumstances" and at least five governors voted to authorize lending under 13(3), the Federal Reserve could discount for IPCs

notes, drafts and bills of exchange ... indorsed or otherwise secured to the satisfaction of the Federal Reserve bank ...

If these conditions were met, the bills of exchange eligible for purchase might be expanded from those meeting the "real bills" criteria to those that are "secured to the satisfaction of the Federal Reserve bank."

However, the Board has not had occasion to interpret the section 14 language on bills of exchange in light of the current language of section 13(3) and its restriction of discounts only to IPCs "unable to secure adequate credit accommodations from other banking institutions." One interpretation would be that, "in unusual and exigent circumstances", the expansion of the authority of the Federal Reserve to purchase bills of exchange beyond those issued for "real bills" purposes may be only for those bills of exchange written by individual IPCs for which the requisite determination that they are unable to secure lending elsewhere has been made. A broader reading might be that the Federal Reserve could expand its purchases of bills of exchange to those indorsed or otherwise secured to the satisfaction of a Federal Reserve Bank. As a practical matter, this issue is likely to be resolved only if economic circumstances bring this matter to the fore.

A third limitation that follows from the first paragraph of section 14 of the Federal Reserve Act is that the purchases of cable transfers, bankers' acceptances, and bills of exchange must be conducted in the "open market." Even if the Federal Reserve wanted to purchase large quantities of bankers' acceptances or bills of exchange, the open market restriction could pose a problem because existing markets for these obligations are not very deep and therefore large open market purchases might not be banks,..... However, as stated by Hackley (p. 23) "It is important to observe again that endorsement by a member bank is not an essential prerequisite to the eligibility of paper for discount; it is simply a condition precedent to the discount of eligible paper." 
feasible. In particular, the volume of bankers' acceptances in recent years has dwindled to about $\$ 25$ billion outstanding on average (at the end of 1996). ${ }^{67}$ Therefore, the scope for purchasing them is quite limited currently. ${ }^{68}$

However, in a period of economic weakness and financial strains, the attempts of the Federal Reserve to improve economic conditions might lead to market responses making these three limitations imposed by the first paragraph of section 14 less binding. First, if the Federal Reserve made known its desire to purchase bankers' acceptances and bills of exchange, private-sector issuance of these instruments might well expand, making the open market restriction less binding. Second, firms and households might be able to restructure their financing arrangements so their credit instruments meet the criteria for bills of exchange. And third, even though the proceeds of the bills of exchange need to meet the "real bills" criteria in usual circumstances, credit is fungible. Funding secured for "real bills" purposes could free up other funds that could be used to finance activities other than "real bills" activities. ${ }^{69}$

Additionally, just as in lending to IPCs, purchases of private-sector assets unavoidably would put the Federal Reserve in a role of assessing and pricing credit risk and affecting the allocation of credit in the economy.

\footnotetext{
${ }^{67}$ Source: Federal Reserve Bulletin, Table A22, October, 1998.

${ }^{68}$ The scope would be even more limited if the discount restriction of the first paragraph of section 14 applies to bankers' acceptances.

${ }^{69}$ The fungibility of credit was one of the reasons Benjamin Strong, Governor of the Federal Reserve Bank of New York, opposed the real bills doctrine and supported conducting monetary policy through open market operations. He stated:

Now as to the limitations [of the real bills doctrine] which the Federal Reserve Act seeks to impose as to the character of paper which a Reserve Bank may discount. When a member bank's reserve balance is impaired, it borrows to make it good, and it is quite impossible to determine to what particular purpose the money so borrowed may have been applied. ... [T]he definition of eligible paper does not affect the slightest control over the use to which the proceeds are applied.
}

See Strong (1930), pp. 182-42. Also see Meltzer (2003) page 263 for a statement of Strong's views. 


\subsection{Purchases of Gold, Foreign Exchange, and Foreign Gov- ernment Obligations}

The Federal Reserve receives authorization to purchase and sell gold and foreign exchange in section 14(a) and the first paragraph of section 14, respectively, of the Federal Reserve Act. The authorization to purchase and sell foreign exchange is granted by the authority to buy and sell cable transfers. ${ }^{70}$ Holdings of gold by the Federal Reserve are also subject to the Gold Reserve Act of $1934 .^{71}$ Under Section 14(b)(1), the Federal Reserve is granted authority to purchase

... obligations of, or fully guaranteed as to principal and interest by, a foreign government or agency thereof.

Such purchases may be done at home or abroad, and are not limited to the open market. $^{72}$

A brief summary of private-sector assets eligible and ineligible for purchase by the Federal Reserve is provided in table 3.

\footnotetext{
${ }^{70}$ See footnote 55.

${ }^{71}$ See Federal Reserve Act And Other Statutory Provisions Affecting the Federal Reserve System (As Amended Through October 1998) (1999), pp. 361-2, for the restrictions imposed on the Federal Reserve holding gold.

${ }^{72}$ This provision was added to the Federal Reserve Act in 1980. At that time, the Federal Reserve made commitments to use this authority to purchase foreign government securities only to invest the System's excess holdings of foreign currency obtained from its normal activities in the foreign exchange market and not to "bail out" foreign governments.
} 
Table 3

Private-Sector Assets Ineligible for Purchase by the Federal Reserve and Those Eligible For Purchase Under Certain Restrictions.*

1. There is No Express Authority for the Federal Reserve to Purchase:

Corporate Bonds

Commercial Paper

Mortgages

Equity

Land (Other than Federal Reserve premises)

2. The Federal Reserve May Purchase

Gold**

Bankers' Acceptances

Bills of Exchange

Subject to:

Restriction 1.

Purchases of foreign exchange, bankers' acceptances, and bills of exchange are to be in the open market.

Restriction 2.

In usual circumstances

The bills of exchange must meet the "real bills" doctrine but, it seems, bankers' acceptances do not.

$\underline{\text { In "unusual and exigent" circumstances }}$

The types of bills of exchange that are eligible to be purchased are open to interpretation.

* In this table, "purchase" does not include the acquisition of instruments by way of discount under the Section 13(2) or similar provisions of the Federal Reserve Act, or promissory notes acquired by the Federal Reserve by way of advances. ** Subject to the Gold Reserve Act of 1934. 


\section{Using Options}

As discussed generally in Clouse et al. (2003) and in more detail in Tinsley (1998), the Federal Reserve might, in some circumstances, believe it would be desirable to enter options markets. The legal authority for such actions, it would seem, may depend upon both the particular options used and the particular purpose to which they are put. Section 4(4), paragraph "seventh" of the Federal Reserve Act gives to the Federal Reserve the power

To exercise by its board of directors, or duly authorized officers or agents, all powers specifically granted by the provision of this Act and such incidental powers as shall be necessary to carry on the business of banking within the limitations prescribed by this Act. ${ }^{73}$

For example, it could be argued that buying or selling options on Treasury securities in certain circumstances is an "incidental" extension of the purchasing and selling of Treasury securities that the Federal Reserve is clearly authorized to undertake. And in some particular circumstances (such as nominal interest rates at or near zero) entering markets for such options may be "necessary to carry on the business of banking within the limitations prescribed by this Act."

The only occasion on which the Federal Open Market Committee has authorized the purchase or sale of options is the authorization aimed at promoting smooth functioning of money and financing markets near 1999 year-end as the potential for Y2K strains increased. Under this temporary authorization, the Federal Reserve Bank of New York sold options on overnight repurchase transactions, with option exercise dates running from December 15, 1999 through January 18, 2000. ${ }^{74}$

\footnotetext{
${ }^{73}$ Emphasis added.

${ }^{74}$ See the September 8, 1999 press release by the Federal Reserve Bank of New York. The press release is available on the web site of the Federal Reserve Bank of New York: www.ny.frb.org. See the "announcements" section under "news items".
} 


\section{Conclusion}

Currently, the Federal Reserve conducts domestic open market transactions (including repurchase agreements) only in securities issued or guaranteed by the U.S. Treasury or federal agencies, and makes loans only to depository institutions. This paper examines the extent to which the Federal Reserve is authorized to expand the scope of its monetary policy operations beyond these current approaches.

In usual circumstances, the Federal Reserve has considerable leeway to lend to depository institutions, but a highly constrained ability to lend directly to individuals, partnerships, and corporations (IPCs). The lending to depository institutions can be accomplished through advances (rather than through discounts) secured by a wide variety of private-sector debt instruments. In discounts for depository institutions, the instruments discounted generally are limited to those issued for "real bills" purposesthat is, agricultural, industrial, or commercial purposes. The Federal Reserve can make loans to IPCs, but, except in unusual and exigent circumstances, the loans must be secured by U.S. Treasury securities or by securities issued or guaranteed by a federal agency.

Also in usual circumstances, the Federal Reserve is authorized to engage in open market operations in gold, foreign exchange, securities issued or guaranteed by the United States or by U.S. agencies, foreign government obligations, and certain obligations of state and local governments. ${ }^{75}$ The Federal Reserve can also purchase private-sector credit instruments, but these are limited to bankers' acceptances and to bills of exchange that meet certain "real bills" criteria. ${ }^{76}$ The Federal Reserve Act contains no explicit language authorizing the Federal Reserve to purchase corporate bonds, bank loans, mortgages, credit-card receivables, or equities.

\footnotetext{
${ }^{75}$ Holdings of gold by the Federal Reserve are also subject to the Gold Reserve Act of 1934 . Regarding foreign government debt, see footnote 72.

${ }^{76}$ See the discussion starting on page 29 of whether the "real bills" restriction also applies to bankers' acceptances.
} 
In "unusual and exigent" circumstances, (and after certain other restrictions are met), the tools of monetary policy could be expanded. In making loans to IPCs, the Federal Reserve would be able to accept a wide variety of private-sector credit instruments as collateral. In open market operations, the Federal Reserve might be able to expand its purchases to include bills of exchange other than those meeting "real bills" criteria.

An important economic issue in both usual and "unusual and exigent" circumstances is whether the Federal Reserve can take onto its balance sheet the credit risk of assets that are purchased or that are used as collateral in loans to depositories or IPCs. Except in unusual and exigent circumstances, it seems to be easier for the Federal Reserve to take (nondepository) credit risk onto its balance sheet in the case of asset purchases than in the case of loans. But even if the Federal Reserve could accept credit risk onto its balance sheet, having the Federal Reserve directly involved in the evaluation of credit risk and influencing the allocation of credit across sectors of the economy would involve its own problems.

Recently, the Federal Reserve has used its "incidental powers" authority to write options contracts on repurchase agreements. However, the use of these powers may depend crucially on the particular options entered into and the particular purpose for which they are entered because the use of this power must be "necessary to carry on the business of banking within the limitations prescribed by [the Federal Reserve] Act." 


\section{Appendix: Bills of Exchange}

Parsons (1863) discusses three features of a bill of exchange: how it can facilitate transactions, the form it takes, and the rights and obligations associated with it. Regarding how a bill of exchange can facilitate transactions, Parsons states:

The bill of exchange is the principal instrument for the transfer of money from place to place. In this respect, it is greatly superior to the promissory note. If, for example, a merchant in New York owed, for goods purchased, one thousand pounds to a merchant in London, he might send him that money in gold or silver; or he might find some one in New York to whom some London merchant owed a thousand pounds, and might give him the money, taking his note for it at sixty days; this note he might send to his London creditor, giving him the name of the [person in London who was in debt to ] the promisor of the note; the London creditor might take the note to the London debtor, who might wish to save himself the trouble of sending the money to New York, and might, therefore, cash the note, and, when his New York creditor demanded payment, he might present to him his note by way of set-off. In this circuitous and inconvenient way both debts would be paid, and no money be sent across the ocean in either direction, one debt being made to pay the other debt.

But the same result may be obtained more directly and conveniently by means of a bill of exchange. Let the New York debtor, whom we will call A, buy for a thousand pounds in dollars a written order from the New York creditor B, addressed to the London debtor C, requiring him to pay that amount to the order of $\mathrm{A}$. Upon this $\mathrm{A}$ indorses an order to $\mathrm{C}$ to pay it to his London creditor D, and transmits it to D, who presents it for payment to $\mathrm{C}$, and, receiving his money, both debts are paid. (pp. 52-53, Vol. 1) 
In terms of the form of a bill of exchange, Parsons states:

Such an order would be a bill of exchange. It would, generally, be in this form. 'New York, January 5, 1857. Value received, please pay to A, or order, one thousand pounds, in sixty days after sight, on account of your obedient servant, B. To C, London.' Here B is the drawer; C is the drawee; A is the payee. As soon as D received the bill, with the order which A indorses upon it making it payable to him, he would, with all convenient promptitude, present it to $\mathrm{C}$; firstly, that the sixty days after sight might begin to run; secondly, that he might know certainly whether $\mathrm{C}$ would pay the money as ordered. This presentment, therefore, is called a presentment for acceptance; because $\mathrm{C}$ must do one thing or the other, that is, he must accept the bill, and this he usually does by writing across the face of it the word 'Accepted,' with a date, and signing his name below the word; or he must refuse to accept the bill. ... (p. 53, Vol. 1)

Regarding the rights and obligations associated with a bill of exchange (and comparing them with those of a promissory note), Parsons states:

The maker or signer of a promissory note, by signing and delivering it, comes at once under an absolute obligation to pay it according to its tenor to any holder to whom it may be due at maturity; and such holder must look to the maker in the first place, and demand it of him in the manner prescribed by law, before he can look to any other party. Not so with the drawer or signer of a bill of exchange. He too comes under an obligation to pay it; but it is only an obligation to pay it if the drawee, or person whom he orders to pay the money, fails to pay it. For the payee, by receiving this order, undertakes to look to the drawee, and use the methods which the law prescribes to get payment from him. The making and delivery of the bill put the drawee under no obligation whatever beyond those which 
exist from the relations between him and the drawer. When it is presented to him, he can accept it or not; but if he does accept it, then he comes at once under an absolute obligation to pay the bill according to its tenor. ... The acceptor is bound absolutely to pay the bill; the drawer is bound to pay it if the acceptor does not; and the payee, having indorsed the bill, is bound to pay it if the drawer does not.

[The drawer] is not only bound to pay the bill if the acceptor does not, but he is bound to pay it if the drawee refuses to accept it. By such refusal there is no acceptor, and no person primarily bound to pay it. But that refusal was one of the conditions on which the drawer engages to pay it, because by drawing he engages that the drawee shall accept the bill on presentment. Therefore if acceptance be refused, the obligation of the drawer may be made absolute at once by due notice ... (pp. 54-55, Vol. 1. underlining added)

Thus, in addition to facilitating "the transfer of money from place to place", the use of a bill of exchange (rather than a promissory note) also affects the credit risk incurred by the creditor. If the debt transaction had been undertaken by means of a 6-month promissory note issued by the New York merchant and held by the London creditor, then the London creditor would be incurring the credit risk of the New York merchant for six months. But with the bill of exchange, the London merchant incurs the credit risk of the New York merchant only until (and if) the London merchant presents the bill of exchange to party $\mathrm{C}$ (the drawee) and the bill is accepted by $\mathrm{C}$. Then the London creditor incurs the credit risk of $\mathrm{C}$ going forward. Even if the bill of exchange is not accepted by $\mathrm{C}$, the time over which the London merchant incurs the credit risk of the New York merchant still is shortened (relative to the case of a promissory note) In this case, the London merchant can make a demand on the New York merchant for immediate payment (after making protest for nonacceptance). 


\section{References}

Acceptance, discount, and open-market purchases of bankers' acceptances, Federal Reserve Bulletin, March 1923, 9, 316-319.

Beebe, Jack and Christine Cumming, "Principles and Illustrations for Federal Reserve Portfolio Selection and Management," 2002. Beebe and Cumming are from the Federal Reserve Banks of San Francisco and New York, respectively. Forthcoming, Board of Governors of the Federal Reserve System, Washington, D.C.

Bigelow, Melville M., The Law of Bills, Notes, and Checks, third ed., Boston: Little, Brown, and Company, 1928. Revised and Enlarged by William Minor Lile.

Chandler, Lester V., The Economics of Money and Banking, New York: Harper and Row, 1948.

Clouse, James A., "Recent Developments in Discount Window Policy," Federal Reserve Bulletin, November 1994, 80, 965-977.

Clouse, James, Dale Henderson, Athanasios Orphanides, David Small, and Peter Tinsley, "Monetary Policy When the Nominal ShortTerm Interest Rate is Zero.," Topics in Macroeconomics, 2003, 3 (1). www.bepress.com/bejm/topics/vo3/iss1/art12.

Congressional Record, Vol. 51, 1913. Also see Legislative History, Federal Reserve Act of 1913, volume 4. Board of Governors of the Federal Reserve System.

Conway, Thomas and Ernest M. Patterson, The Operation of the New Bank Act, Philadelphia: J. B. Lippincott Company, 1914.

Daniel, John W., A Treatise on the Law of Negotiable Instruments, New York: Baker, Voorhis and Company, 1903. Fifth Edition.

Federal Reserve Act And Other Statutory Provisions Affecting the Federal Reserve System (As Amended Through October 1998), Washington D.C.: Board of Governors of the Federal Reserve System, 1999. Copies may be obtained from Publications Services, Board of Governors of the Federal Reserve System, MS-138, Washington D.C., 20551.

Federal Reserve Bank of Minneapolis v. First Nat. Bank of Eureka, S.D., 1921. 277 F. 300 (D.S.D. 1921).

Financial Services Institutions: Information for Assessing the Government's Potential Financial Exposure, Washington, D.C.: United States General Accounting Office, June 1998. 
Financial Statistics of the United States, U.S. Department of Commerce, various years.

First Annual Report of the Federal Reserve Board, Washington, D.C.: Government Printing Office, 1915.

Fleming, Michael J., "The Benchmark U.S. Treasury Market: Recent Performance and Possible Alternatives," Federal Reserve Bank of New York Economic Policy Review, forthcoming 2000.

Fundamentals of Banking: How a Bank Works, New York, New York: American Institute of Banking, Section American Bankers Association, 1943.

Garcia, F.L., ed., Glenn G. Munn's Encyclopedia of Banking and Finance, seventh ed., Boston, Massachusettes: Banker's Publishing Company, 1973.

Hackley, Howard H., Lending Function of the Federal Reserve Banks: A History, Washington, D.C.: Board of Governors of the Federal Reserve System, May 1973.

Hakkio, Craig and Rick Lang, "What Could the Federal Reserve Adopt as Discount Window Alternatives to Open Market Operations in Non-Treasury Securities and the Treasury Debt Declines," 2002. Hakkio and Lang are from the Federal Reserve Banks of Kansas City and Philadelphia, respectively. Forthcoming, Board of Governors of the Federal Reserve System, Washington, D.C.

Hardy, Charles O., Credit Policies of the Federal Reserve System, Washington, D.C.: The Brookings Institution, 1932.

Harris, S.E., Twenty Years of Monetary Policy, Harvard University Press, 1933.

Jaffee, Dwight, "The Interest Rate Risk of Fannie MAy and Freddie Mac," Journal of Financial Services Research, 2003, 24:1, 5-29.

Krieger, Sandy and Brian Madigan, "Financial Assets Available for Purchase in the Open Markets," 2002. Krieger and Madigan are from the Federal Reserve Bank of New York and the Board of Governors, respectively. Forthcoming, Board of Governors of the Federal Reserve System, Washington, D.C.

Lowell, Linda, "Mortgage Pass-Through Certificates," in Frank J. Fabozzi, ed., The Handbook of Mortgage Backed Securities, Probus Publishing, 1995.

McKinley, David H., "The Discount Rate and Rediscount Policy," in Herbert. V. Prochnow, ed., The Federal Reserve System, Harper and Brothers, New York, 1960.

Meltzer, Allan H., A History of the Federal Reserve, Volume 1: 1913-1951, Chicago, Illinois: The University of Chicago Press, 2003. 
Monetary Policy and Reserve Requirements Handbook, Washington, D.C.: Federal Reserve Regulatory Service, Board of Governors of the Federal Reserve System, 1998.

Munn, Glenn G., Encyclopedia of Banking and Finance, Bankers Publishing Co. Boston, 1924.

Office of Federal Housing Enterprise Oversight, 2004. Available at www.faniemae.com.

Operation of the National and Federal Reserve Banking Systems, Hearings Before a Subcommittee of the Committee on Banking and Currency, United States Senate, Seventy-First Congress, Third Session, Appendix, Part 6., 1931.

Parsons, Theophilus, A Treatise on the Law of Promissory Notes and Bills of Exchange, Philadelphia: J.B. Lippincott and Co., 1863.

Recission of Regulation E, Federal Register, vol. 43, No. 223, November 17, 53708, 1978.

Recommendations Regarding Operations in Bankers'Acceptances, March 8, 1977. Memorandum to Federal Open Market Committee by the Subcommittee on Bankers'Acceptances.

Reed, Harold L., The Development of Federal Reserve Policy, Boston and New York: Houghton Mifflin Co., 1922.

Report of the System Committee on Eligible Paper, Washington, D.C.: Board of Governors of the Federal Reserve System, 1962.

Rufener, Louis A., Money and Banking in the United States, New York: Houghton Mifflin Company, 1934.

Scott, William A., Money and Banking, New York: Henry Holt and Company, 1916.

Six Voluntary Initiatives, 2004. Available under 'Initiatives' at www.faniemae.com.

Small, David and James Clouse, "The Limits the Federal Reserve Act Places on the Monetary Policy Actions of the Federal Reserve," Annual Review of Banking Law, 2000, 19, 553-579.

Strong, Benjamin, "Control of Credit Through the Reserve System," in Randolph W. Burgess, ed., Interpretations of Federal Reserve Policy in the Speeches and Writings of Benjamin Strong, Harper and Brothers, 1930. 
Tenth Annual Report of the Federal Reserve Board: Covering Operations for the Year 1923, Washington, D.C.: Government Printing Office, 1924.

The American and English Encyclopedia of Law, London and Northport, Long Island, N.Y.: Edward Thpmpson Company, 1897.

The Federal Reserve Discount Window, Washington D.C.: Board of Governors of the Federal Reserve System, 1994.

The Federal Reserve System Purposes and Functions, Board of Governors of the Federal Reserve System, Washington, D.C., 1994. Website address: http://www.bog.frb.fed.us.

Third Annual Report of the Federal Reserve Board, Washington, D.C.: Government Printing Office, 1917.

Tinsley, Peter A., "Short Rate Expectations, Term Premiums, and Central Bank Use of Derivatives to Reduce Policy Uncertainty," September 1998. FRB staff working paper, Financial and Economics Discussion Series (FEDS) 1999-14.

Transcript of the Federal Open Market Committee Meeting of March 16, 1984, Washington, D.C.: Board of Governors of the Federal Rerserve System, 1984.

Twenty-Fourth Annual Report of the Federal Reserve Board: Covering Operations for the Year 1937, Washington, D.C.: Government Printing Office, 1938.

West, Robert Craig, Banking Reform and the Federal Reserve, 1863-1923, Cornell University Press, 1977.

Willis, H. Parker, The Theory and Practice of Central Banking, New York: Harper and Brothers Publishers, 1936.

_ and William H. Steiner, Federal Reserve Banking Practice, New York: D. Appleton and Company, 1926.

Woelfel, Charles J., Encyclopedia of Banking and Finance, Chicago, Illinois: Probus Publising Company, 1994.

Youngdahl, C. Richard, "Open-Market Operations," in Herbert. V. Prochnow, ed., The Federal Reserve System, Harper and Brothers, New York, 1960.

Youngman, Anna, "The Efficacy of Changes in the Discount Rates of the Federal Reserve Banks," American Economic Review, September 1921, pp. pp. 465-485. 